\title{
Crown Ether Ditopic Receptors for Ammonium Salts with High Affinity for Amino Acid Ester Salts
}

\author{
Sharon Rosete-Luna, Felipe Medrano, Margarita I. Bernal-Uruchurtu, and Carolina Godoy-Alcántar* \\ Centro de Investigaciones Químicas, Universidad Autónoma del Estado de Morelos, 62209 Cuernavaca, Morelos, México. \\ Tel/Fax:+52 777329 7997, cga@uaem.mx
}

Received August 13, 2009; accepted November 19, 2009

\begin{abstract}
Two bis crown ether receptors were synthesized and tested as host molecules for protonated forms of alkyl amines and amino acid esters. Molecular recognition studies were conducted in $\mathrm{CH}_{2} \mathrm{Cl}_{2}: \mathrm{MeOH}$ (92:8) by spectrophotometric UV/Vis titrations and by spectrometric ${ }^{1} \mathrm{H}$ NMR titrations in $\mathrm{CDCl}_{3}$. The calculated binding constants are in the range $10^{2}-10^{5} \mathrm{M}^{-1}$. A high affinity for L-amino acid methyl ester derivatives was found. A theoretical study at the DFT level of the synthesized receptor and some analog ligands with three different ammonium ions helps to rationalize the experimentally found trends.
\end{abstract}

Key words: Ditopic Receptors, Binding Constant; Crown Ethers, Alkyl Ammonium, Amino Acid.

\section{Introduction}

Molecular recognition of amines is an interesting field due to their widespread presence in nature. Many biogenic amines such as histamine, cadaverine, and putrescine are used as probes to measure the quality of marine food products [1]. Tyramine is a potent bacterial mutagen that induces tumors at multiple sites in rodents [2]. Dopamine is a well-known neurotransmitter, and epinephrine (adrenaline) is an adrenal hormone. The entire class of alkaloids comprises toxic amines while aliphatic amines have many applications in the chemical industry some of them are considered environmental hazards.

The development of effective receptors for amines has been an area of considerable interest for many years. Crown ethers and heterocrown ethers constituted the earliest hosts or chemosensors for amines, which were recognized primarily in their ammonium forms [3].

Metalloporphyrin hosts were developed to bind neutral amines by coordination to metal cations [4]. These hosts were able to recognize amines in both organic solvents and water [5]. Dynamic covalent chemistry added a new dimension to amine recognition, for example, the reaction of neutral, primary amines with carbonyl groups in dyes to form fluorescent imines [6]. Zimmerman and co-workers provided an element of selectivity by preparing a molecularly imprinted polymer dye for the detection of amines [7]. However some of these hosts have solubility problems, i.e., they are soluble in nonpolar organic solvents while the ammonium ions require polar solvents which limited the potential analytical procedures of study to liquid-liquid extractions [8-13] and transport experi-
Resumen. En este trabajo se sinterizaron dos receptores del tipo bis eter corona y fueron estudiados como moléculas anfitrión de alquilaminas y ésteres de aminoácidos protonados. Se realizaron estudios de reconocimiento molecular por titulaciones espectrofotométricas $\mathrm{UV} / \mathrm{Vis}$ en $\mathrm{CH}_{2} \mathrm{Cl}_{2}: \mathrm{MeOH}$ (92:8) y por titulaciones espectrométricas de $\mathrm{RMN}{ }^{1} \mathrm{H}$ en $\mathrm{CDCl}_{3}$. Las constantes de enlace calculadas están en el intervalo $10^{2}-10^{5} \mathrm{M}^{-1}$. Se encontró una alta afinidad por los ésteres metílicos de los L-aminoácidos estudiados. Un estudio teórico a nivel DFT de los receptores sinterizados y algunos ligandos análogos con tres diferentes iones amonio permite explicar las tendencias experimentales encontradas.

Palabras clave: Receptores ditópicos, constante de enlace, éteres corona, alquilamonio, aminoácido.

ments [14-17] and only some host-guest complex have been studied in solution by ${ }^{1} \mathrm{H}$ NMR $[8,18,19]$ or by calorimetric titrations $[20,21]$. In Table 1 we summarize the analytical methods used for their study and their corresponding stability constants.

Functionalized benzocrown ethers are desirable candidates for amine receptor molecules because of their well known ability to form strong complexes with organic cations [3d]. In this work we report the use of two ditopic bis(crown) ethers to detect protonated amine and amino acid derivatives in solution. In Scheme 1 the general preparation method used is presented and in Chart 1 the guest molecules used are indicated. The receptor molecules have in their structure two crown ether moieties linked by a conjugated aromatic bis azomethine unit. These structural units can bind the ammonium group of the guest molecule through H-bonds. The aromatic and conjugated systems in the receptor molecules open the possibility for additional $\pi-\pi$ interactions or van der Waals contacts with the alkyl or aromatic groups of ammonium guest. The ionophores are electronically connected which might introduce allosteric control over the recognition properties. This particular type of ditopic receptors has been used as hosts for alkali and alkaline metals [22] but, to the best of our knowledge, amine and amino acid complexes have not been studied yet. In this work we report the affinity of the bis crown ether receptors towards protonated amines and amino acid ester derivatives in solution. Using theoretical methods at the DFT level we propose the structure of these complexes and some insight on the origin of the trends of the selectivity experimentally observed. 
Table 1. Binding constants for selected host-guest complexes of ammonium organic cations.

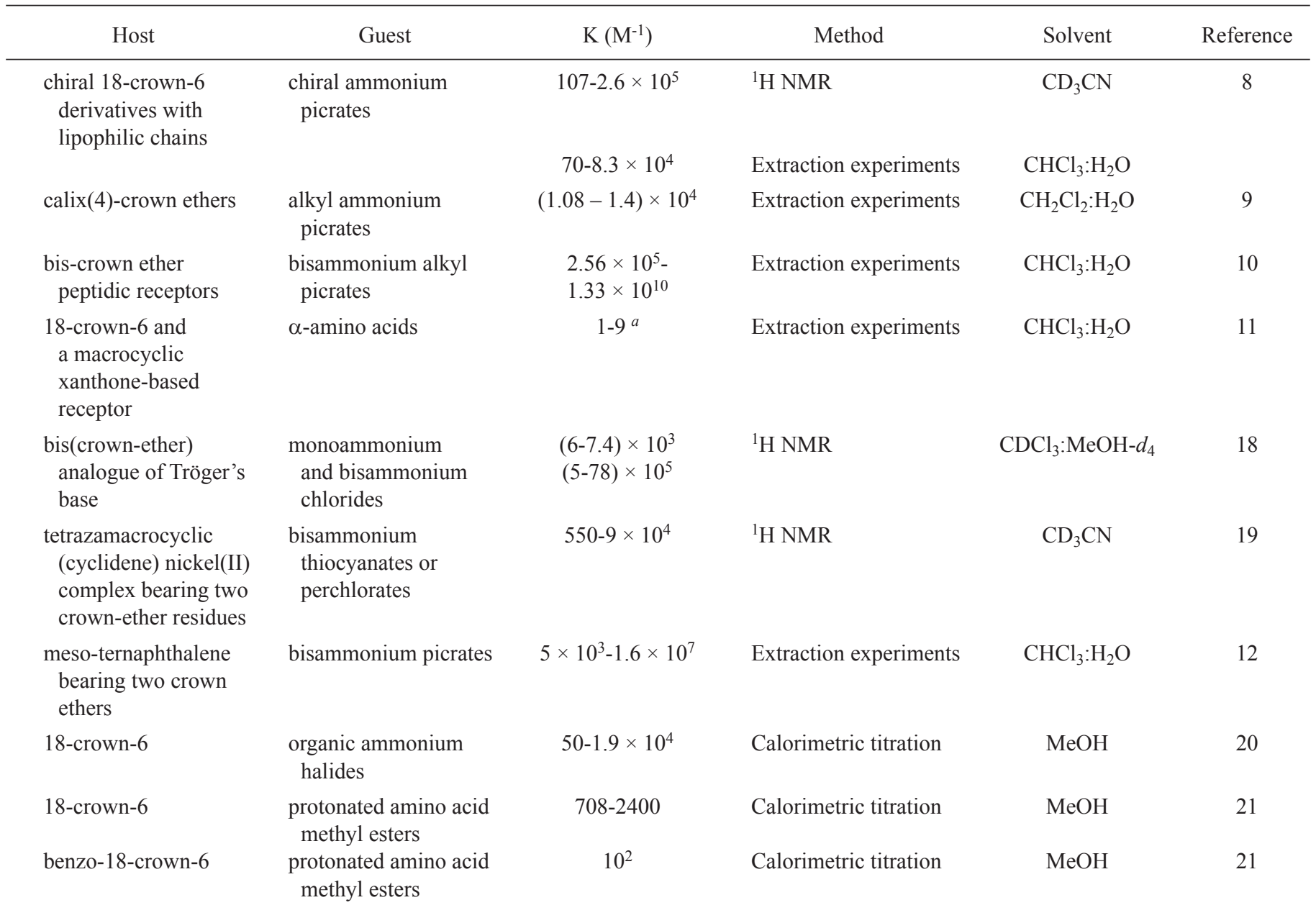

${ }^{a}$ Ratio between the two association constants of both diastereomeric complexes.

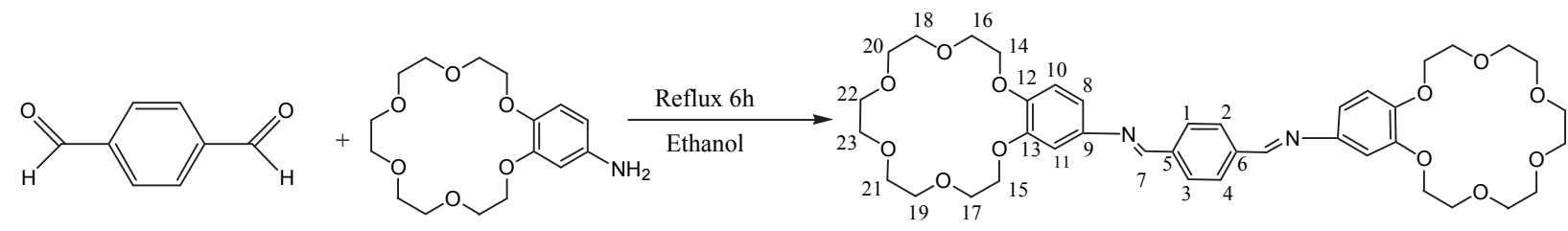

1

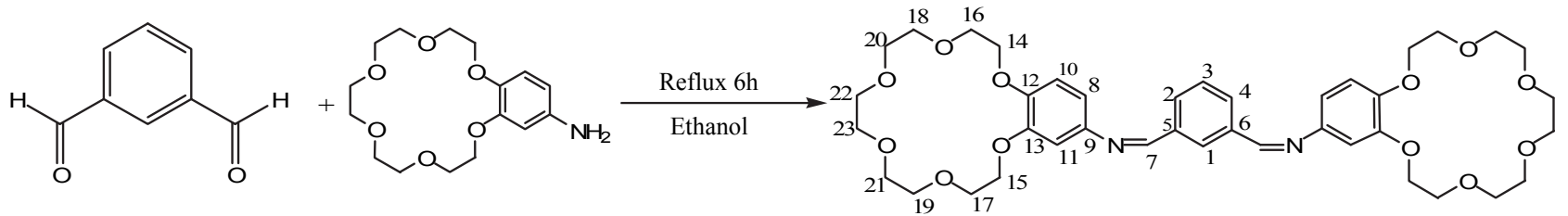

Scheme 1. Synthesis of the host molecules studied in this work. 
<smiles>COC(=O)C(C)[NH2+]Cl</smiles>

A<smiles>Fc1ccccc1CC[NH2+][SiH3]</smiles><smiles>CCCCCCC[NH-]</smiles>

G<smiles>COC(=O)C([NH3+])Cc1ccccc1</smiles>

B<smiles>[NH3+]Cc1ccccc1</smiles>

$\mathbf{H}$

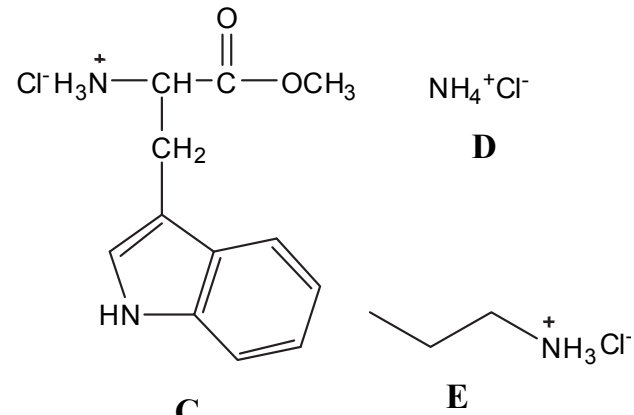

$\mathbf{C}$
$\mathbf{E}$

Chart 1. Chemical structures of the guest molecules studied in this work.

\section{Results and Discussion}

\section{Electronic spectra of receptors associated with ion binding}

Using a mixture of methylene chloride and methanol (92:8) the absorption maxima of receptors $\mathbf{1}$ and $\mathbf{2}$ appears at $\mathbf{3 8 7}$ and 352 $\mathrm{nm}$, respectively. The observed transitions are of $\pi-\pi^{*}$ nature and are attributed to the extended $\pi$ system formed by the three aromatic rings connected by two imine groups present in the receptor structure. The band is highly sensitive to the polarity of the solvent, methanol addition to a $\mathrm{CH}_{2} \mathrm{Cl}_{2}$ solution of receptor 1, leads to a hypochromic effect of $380 \mathrm{~nm}$ band (Supplementary material) This solvatochromic behaviour has been explained as due to a hydrogen bond formation between imine groups of the receptor molecule and the hydroxyl group of the methanol [23].

Addition of the ammonium salts result in hypsochromic and hypochromic shifts of the receptors bands as it is shown in Fig. 1. These shifts might be explained in terms of the conformational changes occurring upon complexation on the $N, N^{\prime}$-( $p$-phenylenedimethylidyne)dianiline structural unit that connects both crown ethers (vide infra).

Receptor molecules are fluorescent in acetonitrile solution with two emission bands located at $307 \mathrm{~nm}$ and $355 \mathrm{~nm}$ when a $250 \mathrm{~nm}$ excitation radiation is used. Titration of the receptors with alkyl ammonium salts induces a modest enhancement of fluorescence intensity which can be rationalized in terms of photoinduced electron transfer effect due to the coordination of non-bonded oxygen electron pairs of the crown ethers. However, calculation of any association constant from these data was not possible.

\section{Binding constants}

The binding constants between receptors 1 and $\mathbf{2}$ and the ammonium salt guests were determined by UV/Vis and ${ }^{1} \mathrm{H}$

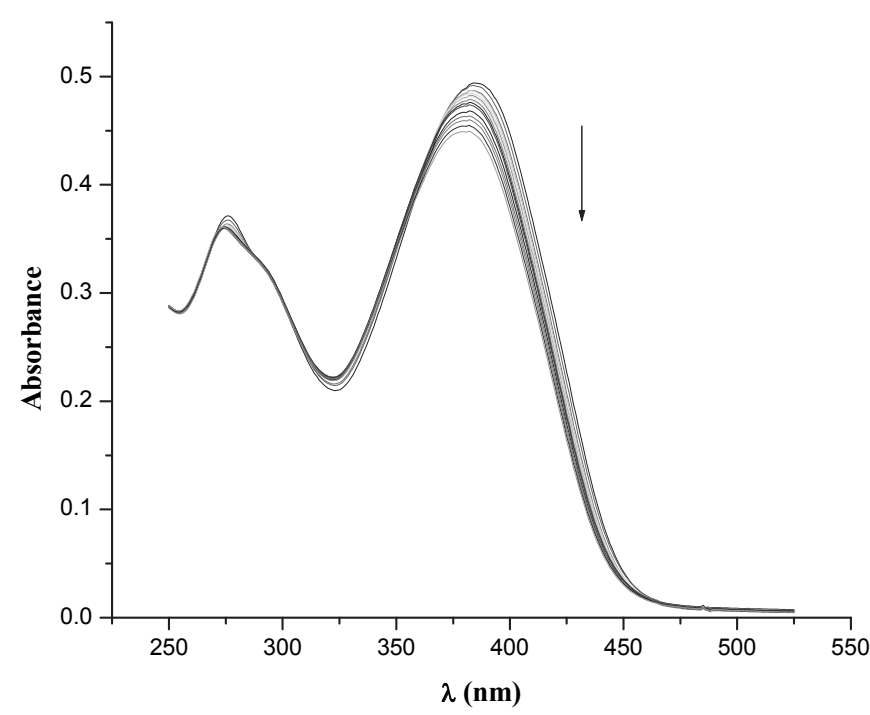

Fig. 1. Changes of the absorption spectra during the titration of 1 $\left(1.5 \times 10^{-5} \mathrm{M}\right)$ with $\mathbf{F}\left(0-2.7 \times 10^{-4} \mathrm{M}\right)$ in $\mathrm{CH}_{2} \mathrm{Cl}_{2}: \mathrm{MeOH}(92: 8)$. The arrow indicates the direction of spectral changes occurring with the increasing concentration of $\mathbf{F}$.

NMR measurements. Complex stoichiometry for both receptor molecules was determined by means of continuous variation (Job) method [24], using UV/Vis spectroscopy, which gave a minimum at a mole ratio of 0.5 for a $1: 1$ stoichiometry which corresponds to the stronger complex formed, however Job graphs were no symmetrical suggesting the presence of complexes of higher stoichiometry (Fig. 2). Although the Job's plots indicate the formation of 1:1 host-guest complex the experimental data suggested a more complex association scheme, i.e., a 1:2 host:guest stoichiometry. The changes in the observed absorbance as a function of the guest concentration 


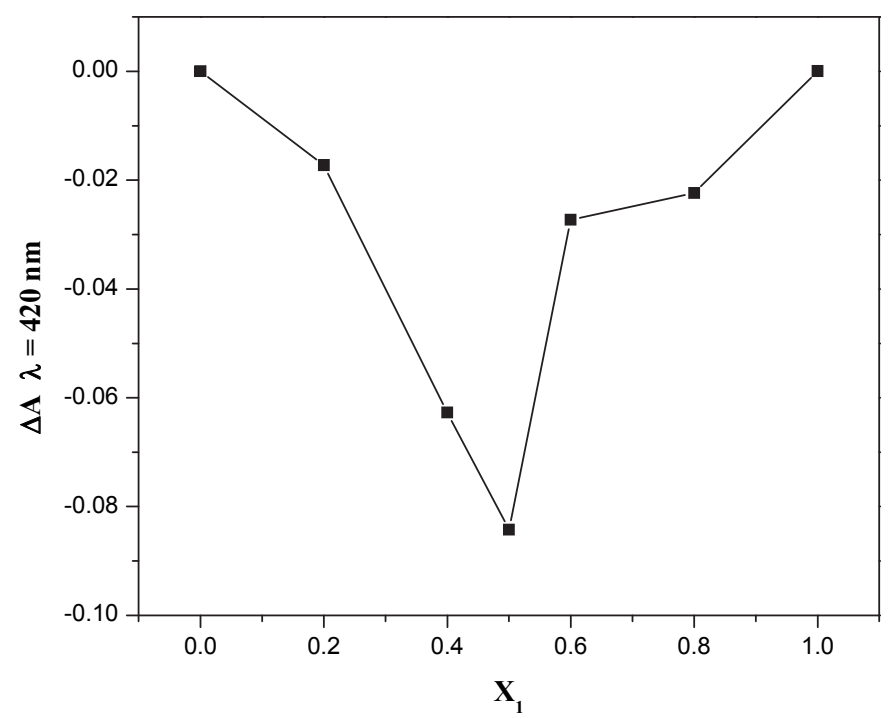

a

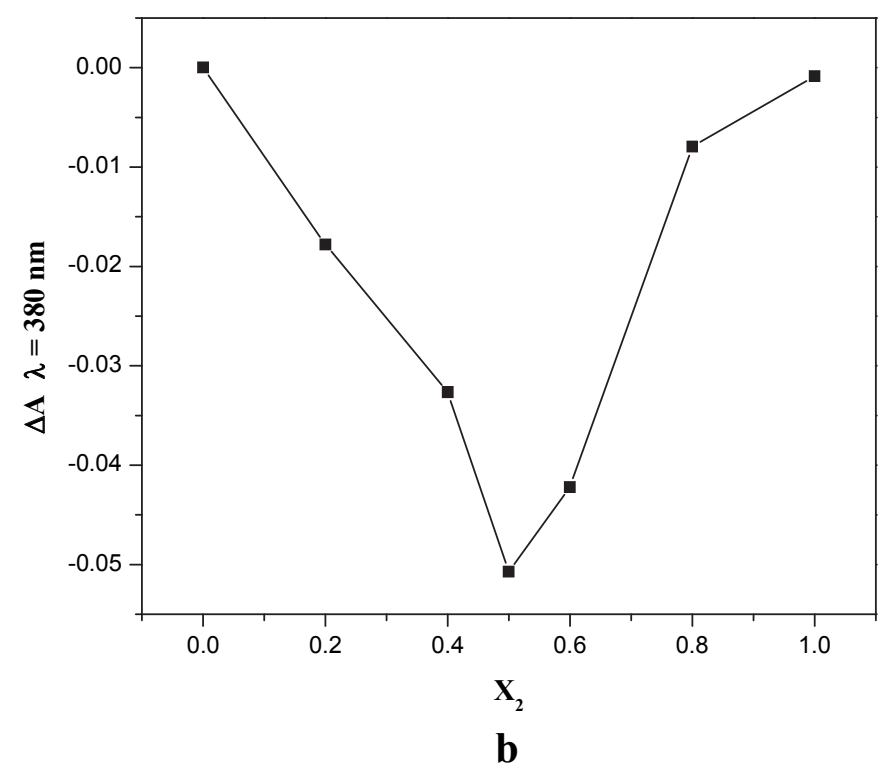

Fig. 2. Continuous variation curve (Job's method) for the (a) 1-G and (b) 2-G complexes observing the variation of the absorbance in host as function of mole ratio of host.

were fitted to equation (1) that considers formation of both 1:1 and 1:2 host:guest complexes.

$$
A_{o b s}=\frac{\left(A_{0}+A_{11} K_{11}[G]_{T}+A_{12} K_{11} K_{12}[G]_{T}^{2}\right)[H]_{T}}{1+K_{11}[G]_{T}+K_{11} K_{12}[G]_{T}^{2}}
$$

where $A_{o b s}$ is the observed absorbance, $A_{0}, A_{11}$ and $A_{12}$ are the absorbances of the free host and its 1:1 and 1:2 respective complexes, $K_{11}$ and $K_{12}$ are the corresponding stepwise formation constants, and $\left[G_{T}\right]$ and $[H]_{T}$ are the total concentrations

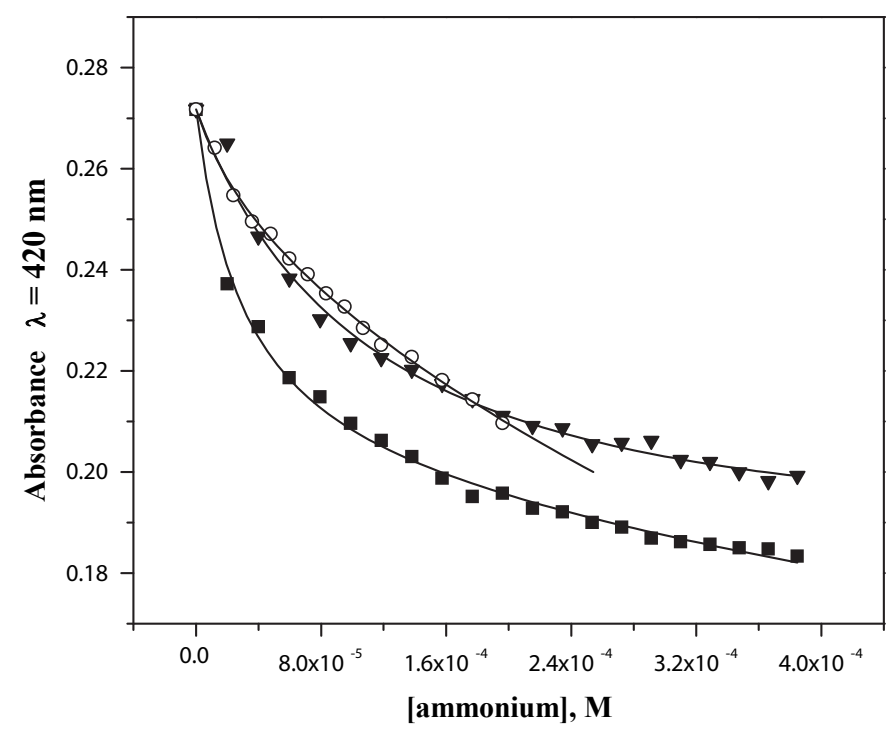

$\mathbf{a}$

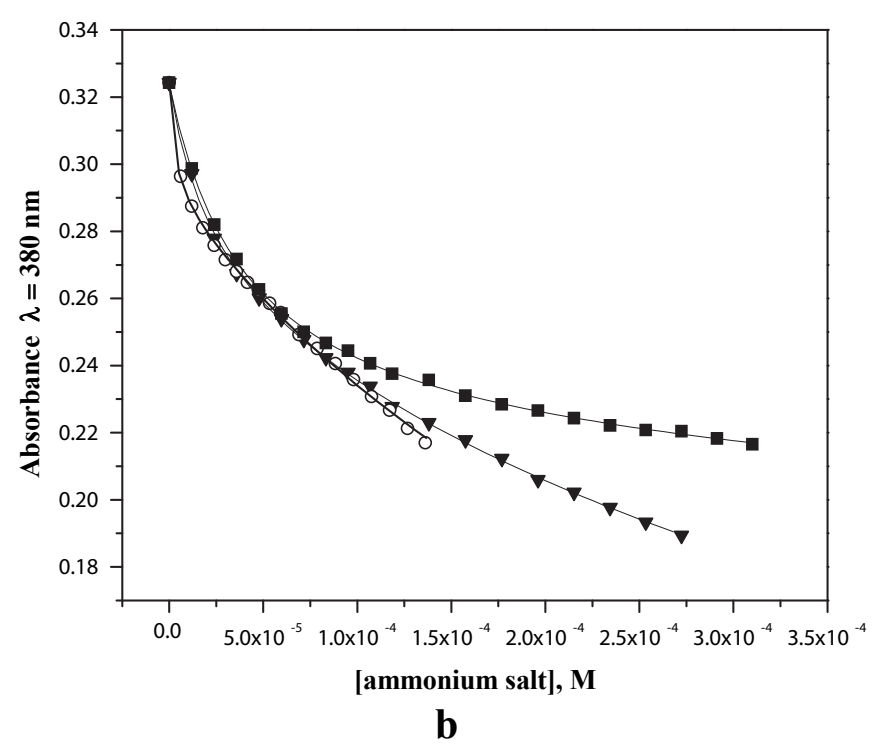

Fig. 3. Typical titration plots for interactions of receptors $1\left[1.5 \times 10^{-5}\right.$ $\mathrm{M}]$ (a) and $2\left[1.6 \times 10^{-5} \mathrm{M}\right]$ (b) with ammonium chlorides in $\mathrm{CH}_{2} \mathrm{Cl}_{2}$ : $\mathrm{MeOH}$ (92:8). Open circles: A, down triangles: $\mathbf{E}$ and squares: $\mathbf{G}$. The solid lines are the fitting curves in accordance with equation 1.

of the guest and host, respectively. The equation is valid for conditions with a high excess of the guest over the host, which were fulfilled in the titration experiments. In Fig. 3 some examples of the typical titration plots are shown. The average binding constants calculated for the different guests are listed in Table 2.

The binding constants were also calculated by fitting the ${ }^{1} \mathrm{H}$ NMR chemical shifts of the host protons in the receptors as function of the guest (A and $\mathbf{G}$ ) concentration using equation 2 that considers a 1:1 stoichiometry and assumes that the total concentrations of host and guest are similar to each other [25]. 
$\delta_{o b s}=\delta_{H}+0.5 \Delta \delta \frac{\left([H]_{T}+[G]_{T}+\frac{1}{K}-\sqrt{\left([H]_{T}+[G]_{T}+\frac{1}{K}\right)^{2}-4[H]_{T}[G]_{T}}\right)}{[H]_{T}}$

where $\delta_{\mathrm{H}}$ is the chemical shift of a given proton of the host, $\Delta d$ is the difference between the chemical shift of the proton in the complex and in the free host (complexation-induced shift at saturation, CIS), $[H]_{T}$ is the total concentration of the host, $[G]_{T}$ is the total concentration of the guest and $K$ is the binding constant. CIS values for the protons of the receptors used in this work are given in Table 3. Typical titration plots are

Table 2. Binding constants for the host-guest complexes in $\mathrm{CH}_{2} \mathrm{Cl}_{2}$ : MeOH: (92:8) determined by UV/Vis spectroscopy $\left(25^{\circ} \mathrm{C}\right)$.

\begin{tabular}{ccrcc}
\hline \multicolumn{5}{c}{ Host } \\
Guest & \multicolumn{2}{c}{$\mathbf{1}$} & \multicolumn{2}{c}{$\mathbf{2}$} \\
& \multicolumn{2}{c}{$\lambda=420 \mathrm{~nm}$} & \multicolumn{2}{c}{$\lambda=380 \mathrm{~nm}$} \\
\cline { 2 - 5 } & $K_{11}\left(\mathrm{M}^{-1}\right)$ & $K_{12}\left(\mathrm{M}^{-1}\right)$ & $K_{11}\left(\mathrm{M}^{-1}\right)$ & $K_{12}\left(\mathrm{M}^{-1}\right)$ \\
\hline A & $62626 \pm 7486$ & $1072 \pm 6$ & $119411 \pm 11064$ & $1828 \pm 19$ \\
B & $a$ & $a$ & $88594 \pm 6220$ & $2659 \pm 5$ \\
C & $a$ & $a$ & $141882 \pm 2365$ & $1933 \pm 8$ \\
D & $18610 \pm 395$ & $123 \pm 21$ & $28505 \pm 382$ & $679 \pm 1$ \\
E & $21542 \pm 292$ & $120 \pm 18$ & $35505 \pm 35$ & $1214 \pm 6$ \\
F & $70067 \pm 3633$ & $1224 \pm 6$ & $19029 \pm 34$ & $a$ \\
G & $31891 \pm 974$ & $267 \pm 11$ & $25662 \pm 400$ & $127 \pm 14$ \\
H & $39960 \pm 584$ & $799 \pm 6$ & $20245 \pm 295$ & $a$ \\
\hline
\end{tabular}

${ }^{a}$ No interaction detected.

Table 3. Complexation-induced ${ }^{1} \mathrm{H}$ NMR chemical shifts (CIS) of the host protons ${ }^{a}$ in host-guest complexes with the ammonium chlorides $\mathbf{A}$ and $\mathbf{G}$ in $\mathrm{CDCl}_{3}$ (in ppm).

\begin{tabular}{lcccc}
\hline & \multicolumn{5}{c}{ Guest } \\
\cline { 2 - 5 } & \multicolumn{3}{c}{$\mathbf{A}$} & \multicolumn{3}{c}{$\mathbf{G}$} \\
\cline { 2 - 5 } Host proton & $\mathbf{1}$ & $\mathbf{2}$ & $\mathbf{1}$ & $\mathbf{2}$ \\
\hline $\mathrm{CH}_{2(13,14)}$ & 0.027 & $-b$ & $-b$ & 0.047 \\
$\mathrm{CH}_{2(15,16)}$ & 0.016 & $-b$ & $-b$ & $-b$ \\
$\mathrm{CH}_{2(21,22)}$ & $-b$ & $-b$ & $-b$ & 0.064 \\
$\mathrm{H}_{(1)}$ & $-b$ & $-b$ & 0.026 & 0.054 \\
$\mathrm{H}_{(2)}$ & $-b$ & $-b$ & 0.026 & 0.026 \\
$\mathrm{H}_{(3)}$ & $-b$ & 0.015 & 0.026 & 0.018 \\
$\mathrm{H}_{(4)}$ & $-b$ & $-b$ & 0.026 & 0.028 \\
$\mathrm{H}_{(6)}$ & 0.058 & 0.054 & 0.047 & $-b$ \\
$\mathrm{H}_{(11)}$ & $-b$ & $-b$ & $-b$ & 0.055 \\
\hline
\end{tabular}

${ }^{a}$ Numbers in parentheses correspond to labels of the protons as shown in Scheme 1.

${ }^{b}$ Not determined because of signal overlapping. shown in Fig. 4 and averaged binding constants are collected in Table 4.

Table 2 contains the calculated values of $K_{11}$ and $K_{12}$ for both host molecules. From these data it results evident that, for all the studied cases, the 1:1 complex is more stable than the corresponding 1:2 complex in agreement with the sharpness of the Job's plot. The $K_{11}$ data obtained for receptor 1 shows that the binding constants values for the protonated amines increase in the order $\mathbf{D}<\mathbf{E}<\mathbf{G}<\mathbf{H}<\mathbf{A} \approx \mathbf{F}$. At a glance, the order found suggests that stability might be related with the amount of contact surface between host and guest as well as the type of the interactions established between them. Ammonium ion (D) binds to the crown ether only with hydrogen bonds whereas, alkyl ammonium ions (E, G) can establish van der Waals

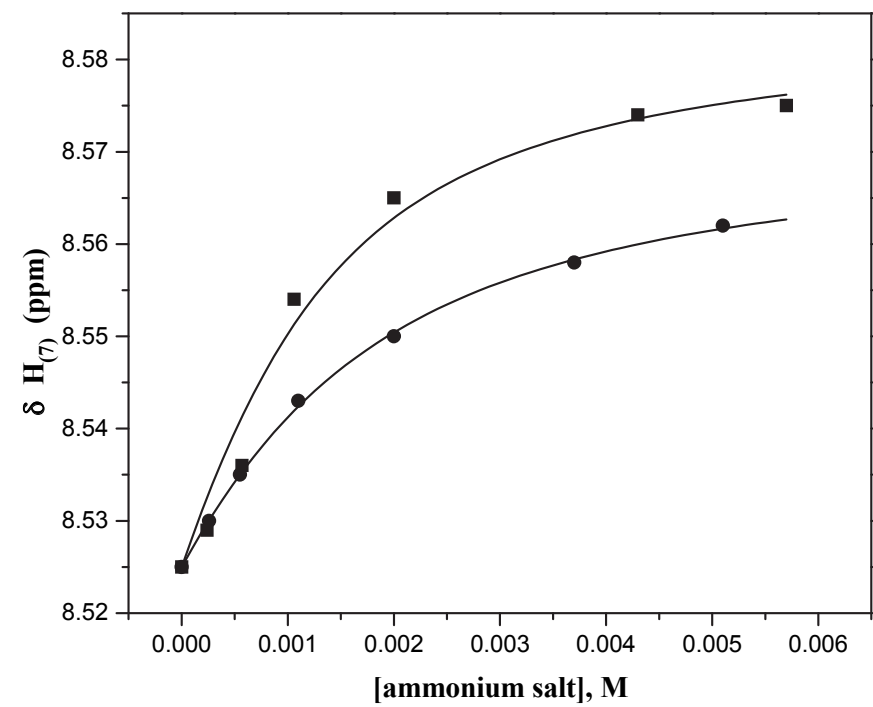

a

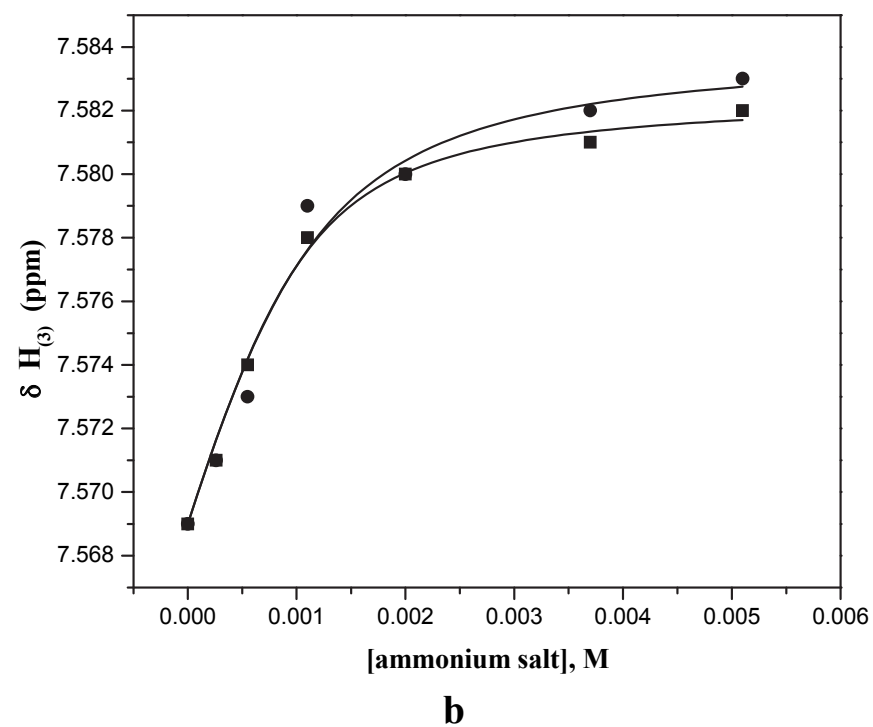

Fig. 4. Typical titration plots for interactions of receptors $1\left[1 \times 10^{-3}\right.$ $\mathrm{M}]$ (a) and $2\left[1 \times 10^{-3} \mathrm{M}\right]$ (b) with ammonium chlorides in $\mathrm{CDCl}_{3}$. Squares: A and circles: $\mathbf{G}$. The solid lines are the fitting curves in accordance with equation 2 . 
Table 4. Binding constants for the host-guest complexes determined by ${ }^{1} \mathrm{H} \mathrm{NMR}$ in $\mathrm{CDCl}_{3}$ at $20{ }^{\circ} \mathrm{C}$.

\begin{tabular}{lccccc}
\hline & \multicolumn{5}{c}{$\operatorname{Host}, \mathrm{K}\left(\mathrm{M}^{-1}\right)$} \\
\cline { 3 - 6 } & & & & & \\
Guest & $18 \mathrm{C} 6$ & $\mathrm{~B} 18 \mathrm{C} 6$ & $\mathrm{NB} 18 \mathrm{C} 6$ & $\mathbf{1}$ & $\mathbf{2}$ \\
\hline $\mathbf{A}$ & $3114 \pm 1434$ & $849 \pm 34$ & $2288 \pm 399$ & $2176 \pm 730$ & $3095 \pm 375$ \\
$\mathbf{G}$ & $2551 \pm 627$ & $274 \pm 11$ & $652 \pm 42$ & $1024 \pm 125$ & $575 \pm 51$ \\
\hline
\end{tabular}

interactions that increase with the length of the chain, and if the guest molecule has an aromatic ring $(\mathbf{H}, \mathbf{F})$ located at the appropriate distance it can also establish $\pi-\pi$ interactions, all of them resulting in an enhancement of the overall binding. For that reason, it is quite surprising that a small amino acid derivative as L-alanine methyl ester (A) has a binding comparable to that of $\mathbf{F}$ while for larger amino acids, like $\mathbf{B}$ or $\mathbf{C}$, no interaction was detected.

In the case of receptor 2 a regular trend of binding affinity was not found. However, from the calculated binding constants presented in Table 2 it is evident that the complexes with L-amino acid methyl esters have the largest stability constants of the studied guests but all these values are lower than those reported from extraction $[10,12]$ or from NMR $[18,19]$ experiments with similar receptors. A similar trend was observed by ${ }^{1} \mathrm{H}$ NMR titrations (Table 4) in which it is possible to compare the association constants for heptyl ammonium and L-alanine methyl ester.

For all the studied cases the $K_{12}$ is at least one order of magnitude smaller than $K_{11}$ thus, the $K_{12} / K_{11}$ ratio explains the strong negative allosteric effect observed. This cooperative effect is well known and has been amply discussed in the literature [26]. It is now accepted that the two crown units act independently with respect to complexation when the ratio of association constants $K_{12} / K_{11}$ is larger or equal to 0.25 . A negative cooperative effect occurs when this ratio is smaller than 0.25 , a positive effect is said to happen in the opposite case [27].

To compare the relative contributions to the stabilities coming from the different structural units in the host molecules the complexation of $\mathbf{A}$ and $\mathbf{G}$, as typical guests of amine and amino acid salts was studied with the 18-crown-6 (18C6), 18-benzocrown-6 (B18C6) and the monoimine (NB18C6). The results obtained by ${ }^{1} \mathrm{H}$ NMR titrations show that receptor 2 has the highest selectivity with a $\mathrm{K}_{\mathrm{A}} / \mathrm{K}_{\mathrm{G}}$ ratio of ca. 5 (Table 4 ). The presence of a benzo azo methine substituent on the B18C6 increases the affinity of the receptors. In the case of receptor 2 the presence of a bis azo methine increases the selectivity.

The interaction between the receptors $\mathbf{1}$ and $\mathbf{2}$ with bisammonium guests (as 1,6-hexanediammonium and $m$-xililendiammonium) was explored by ${ }^{1} \mathrm{H}$ NMR experiments. However, when one equivalent of bisammonium salt is added to a solu- tion of the host the hydrolysis of imine bond was observed as was deduced by the rise of aldehyde signal in the NMR spectrum.

\section{Computational studies}

In order to gain insight into the characteristics of the interactions between the guest ions and receptor 1, the stable gasphase structures of three single receptor molecules, $18 \mathrm{C} 6$, B18C6, and NB18C6 as well as their complexes with D, E and A were studied using DFT methods (B3LYP/6-31G(p)). The optimized stable structures of NB18C6 and its complex with A are shown in Fig. 5. The properties of these complexes are compared with the properties of the optimized stable structures of receptor 1 complexes. A stable structure of receptor $\mathbf{1}$ is shown in Fig. 6 and two of the studied complexes are presented in Fig. 7.

The optimized geometry of $18 \mathrm{C} 6$ corresponds to the $S_{6}$ conformer that has been described as the most stable conformer predicted with DFT and MP2 ab initio methods [28].
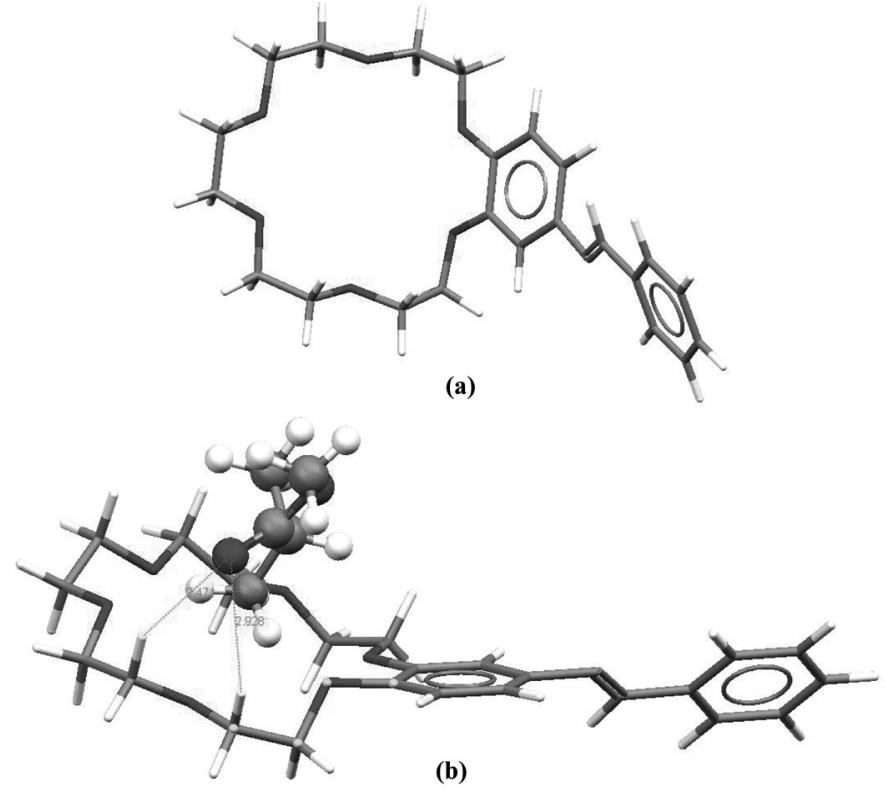

Fig. 5. B3LYP/6-31G* optimized structures of NB18C6, (a) and its complex with L-alanine methyl ester (b) The $\mathrm{C}=\mathrm{O} \cdots \mathrm{H}_{2} \mathrm{C}$ distances are in $\AA$ and the highlighted atoms (yellow) form the dihedral angle $C_{\text {benzo }}-O-C_{\text {met }}-C_{\text {met }}$ mentioned in the text.

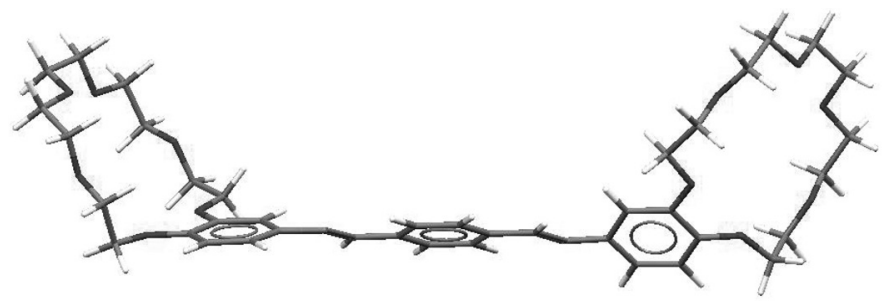

Fig. 6. B3LYP/6-31G* optimized structure of receptor 1 . 

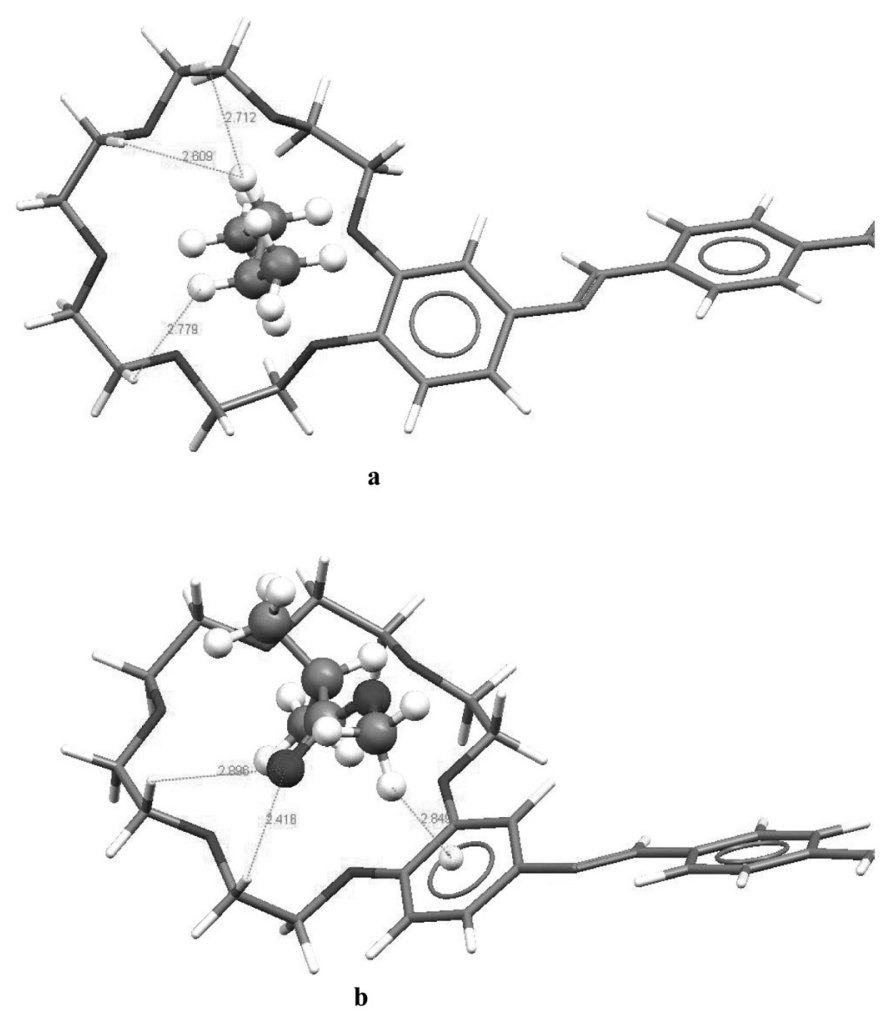

Fig. 7. Fragment of the B3LYP/6-31G* optimized structures of the complex formed between receptor $\mathbf{1}$ and propil ammonium (a) and L-alanine methyl ester (b). H-bonds and close contact distances are in $\AA$. The white dot over the aromatic ring corresponds to the calculated centroid.

For B18C6 was found that aromatic ring lies in the same plane as the two the donor oxygen atoms directly attached to it. As some authors have pointed out [29], the size of the cavity is not affected by the presence of the benzo group however, the basicity of the donor groups and the shape of the cavities are different. The structure of the B18C6 fragment is preserved in NB18C6 and in receptor 1. In these free ligands, the phenyl group of the benzo crown ether and the aromatic bis-imine moiety form an extended conjugated system and the angle formed between the planes containing them is $\sim 29^{\circ}$. This value is in good agreement with what is found in the crystal structure of N,N'-( $m$-phenylenedimethylidyne)dianiline [30].

It has been discussed that the size of the $\mathrm{NH}_{4}^{+}$ion $(1.4 \AA)$ and the $-\mathrm{NH}_{3}{ }^{+}$group make of this species ideal guests on the 18C6 cavity $(\sim 1.42 \AA)$ where they are stabilized through three hydrogen bonds disposed in a three-fold symmetry pattern [29, 31]. In the case of ammonia (D), the average $\mathrm{N}-\mathrm{H} \cdots \mathrm{O}$ distance was found to be $1.83 \AA$. For the other guest molecules, the presence of the $\mathrm{R}$ - substituent on the $\mathrm{NH}_{3}{ }^{+}$group affects the fit leading to a less symmetrical coordination pattern with longer H-bonds, $1.87 \pm 0.01 \AA$ for $\mathbf{E}$ and $1.92 \pm 0.05 \AA$ for $\mathbf{A}$. In the case of the B18C6 complexes it was found that the three H-bonds have different lengths for all the studied cases. The lack of symmetry in this latter case is not only related with the differences on the ether conformation but also with a conformational change occuring as consequence of the complex formation; the dihedral angle $C_{\text {benzo }}-O-C_{m e t}-C_{m e t}$ changes from $\sim 80^{\circ}$ to $\sim 160^{\circ}$. It is expected that electronic changes go along with this structural modification. Besides the H-bonds, the intermolecular distances between the host and the guest molecule strongly suggest the presence of additional interactions: the methylene groups of $\mathbf{E}$ are close to one of the ether oxygens $(2.8-2.9 \AA)$ and in the case of $\mathbf{A}$ the oxygen atoms of the carbonyl ester group are close to the methylene hydrogens of the crown ether (2.4 and 2.8 $\AA$ ). Upon complex formation, receptor 1 undergoes further conformational changes, the twist between the aromatic rings connecting the crown ether rings decreases by c.a. 10 on the side where the complex is formed but this is counterbalanced by an equivalent increase in the twist of the free side. However, on the double complex (1:2) the decrease in the twist is symmetric.

The interaction energies for all the studied complexes, were obtained as: $E_{\text {int }}=E_{\text {complex }}-\left(E_{\text {host }}+n E_{\text {guest }}\right)$, where $E_{\text {complex }}$, $E_{\text {host }}$, and $E_{\text {guest }}$, are the total energies of the corresponding optimized structures and $n$ is the number of guest molecules per complex. The interaction energies of ammonium ion complexes are larger than that of $\mathbf{E}$ and $\mathbf{A}$ with all the ligands considered in this study. For that reason the interaction energy calculated for the 18C6-D complex will be considered as an internal reference for the following discussion. The relative interaction energies, $\Delta E=E_{\text {int }}^{X}-E_{\text {int }}^{N H_{4}^{+}}$, are presented in Table 5 .

The differences on the interaction energies of 18C6 and B18C6 complexes are not very large and can be rationalized in terms of two situations: first, the increased basicity of the two oxygen atoms attached to the benzo group with respect to the others does not result in stronger H-bonds. And second, the energetic cost associated with the conformational change occurring on the ether ring, estimated from a scan of the pertaining torsion barrier, for both guest molecules is less than $1.5 \mathrm{kcal} / \mathrm{mol}$. Both situations lead to a very small difference between 18C6 and B18C6 for $\mathbf{E}$ but a more favourable bonding situation for A with B18C6. The interaction energies of the NB18C6 complexes reflect not only the steric effect of the ether ring substituent but also the electronic effects of the delocalized system in it. For this reason, it is a better ligand than B18C6 for $\mathbf{E}$ and $\mathbf{A}$, but no for the ammonium ion. Furthermore, it is also possible that the additional non-covalent interactions, $\mathrm{C}-\mathrm{H} \cdots \mathrm{O}$ type, might be a small contribution to the

Table 5. Relative interaction energies, $\Delta E=E_{\text {int }}^{H-G}-E_{\text {int }}^{18 C 6-D}$, for the 1:1 complexes with the studied ligands. All values are in $\mathrm{kcal} / \mathrm{mol}$.

\begin{tabular}{rcccc}
\hline & \multicolumn{4}{c}{ Ligands } \\
\cline { 2 - 5 } Guest & $18 \mathrm{C} 6$ & B18C6 & NB18C6 & $\mathbf{1}$ \\
\hline D & 0.0 & 4.3 & 4.9 & 4.1 \\
$\mathbf{A}$ & 18.9 & 19.5 & 17.6 & 12.1 \\
$\mathbf{E}$ & 10.6 & 14.9 & 13.0 & 16.8 \\
\hline
\end{tabular}


stability. In this case, their presence, suggested by the distance values between the relevant groups, does not have a noticeable effect in the total interaction energies. Further investigation of the role these interactions have in the stability of these complexes requires the use of ab initio methods [32]. From the interaction energies of the complexes formed with receptor 1 it is evident that the electronic effects related with the presence of the large conjugated system attached to the ether ring make of this ligand a much better host for both $\mathbf{E}$ and $\mathbf{A}$ than any other of the considered ligands.

The interaction energies for the double complex of receptor $1(1: 2)$ were calculated in the same way that for the $1: 1$ complexes. The comparison of these interaction energies with the corresponding values for the 1:1 complexes of receptor $\mathbf{1}$ is a measure of the cooperative effects in the system. For the three studied cations the interaction energy of the double complex is smaller than the double of the corresponding interaction energy of the 1:1 complex. However, there are significant differences in the non-additivity for each system. For $\mathbf{D}$, the interaction energy is $16.2 \%$ less attractive than the expected value for a fully additive system; this difference was considerably more important for $\mathbf{E}, 31.3 \%$ and rather small for $\mathbf{A}$, only $6.6 \%$.

\section{Discussion}

In this study, the theoretical results are useful to better understand the experimentally observed behaviour of these receptors. The single most important change taking place upon complexation is the conformational change occurring in the ligands, in the crown ether ring and the aromatic link between the two host groups. This structural modification is largely responsible of the changes observed in the UV/Vis spectra and the shifting of some protons in the crown ether to low field as observed on the CIS. The negative allosteric effect found is also a consequence of this conformational change. The binding of any guest ion to one of the benzocrown units affects the electronic density of the oxygen atoms on the unoccupied crown ether lowering its basicity. In conjugated bis-crown receptors, the first cation, which is electron withdrawing, can modify the electron environment of the second crown. Electrostatic repulsion can also happen when the complexed crowns lie in close proximity. In previous studies, it was found that in benzo and dibenzo crown ethers [33], changes in the charge on the aromatic oxygen in the macrocycle, brought about by change in the nature of the substituent, produced profound effects on the binding constants. Detailed analysis of the complexation data indicates that in general two factors influence the binding ability of the ether ring; the polarizability of the electrons on the ring oxygen and the constraints on the conformational changes that are required to occur for the ring to achieve a minimum conformation around the solvated cation.

The large selectivity observed for the L-alanine cation can be understood as a result of several combined factors; this guest can engage in weak interactions additional to the H-bonds that might confer more dynamical stability to the complex; the aromatic substitution on the crown ethers favour the complex formation with it and, to a smaller extent but also important, the large difference on cooperative effects found from the interaction energies of the 1:1 and 1:2 complexes reflects that the modifications induced by its presence in one of the crown ether rings of receptor $\mathbf{1}$ does not severely impair the other to act as a reasonably good host for another cation.

\section{Conclusions}

The binding constants obtained in this work are comparable with those reported from NMR experiments $[18,19]$ or calorimetric titrations [20] for ammonium cations and one order of magnitude larger than those reported for benzo-18-crown- 6 for protonated amino acid methyl esters obtained from calorimetric titration in methanol [21]. It was found that the receptors reported in this work have high affinity for cationic amino acid salts.

This study confirms the interaction energies of the complex formed are a reasonably good approach to understand the stability constants but it is only the simultaneous consideration of the energetic and structural changes occurring during complex formation that the selectivity of these receptors can be explained.

\section{Experimental}

\section{Materials and spectroscopic measurements}

All reagents and solvents were purchased from Aldrich and Fluka and were used as received. Amine salts were prepared following literature procedures [34] and dried under vacuum. ${ }^{1} \mathrm{H}$ NMR spectra were recorded in $\mathrm{CDCl}_{3}$ at $400 \mathrm{MHz}$ at a probe temperature of $20^{\circ} \mathrm{C}$ on a Varian UNITY INOVA with TMS as internal reference. The electronic spectra were recorded at $25^{\circ} \mathrm{C}$ on a Hewlett Packard 8453A diode array spectrophotometer. FAB mass spectra were obtained on a JEOL JMSSMX102A instrument. Elemental analysis was obtained on an ELEMENTAR Vario ELIII (C, H, N, S) instrument.

\section{UV/Vis titrations}

The spectroscopic titrations were performed at $25^{\circ} \mathrm{C}$, in $\mathrm{CH}_{2} \mathrm{Cl}_{2}: \mathrm{MeOH}$ : (92:8). Aliquots of concentrated solution of a guest $\left(1 \times 10^{-2} \mathrm{M}\right.$ for ammonium salts $\mathbf{D}-\mathbf{H}$ and $5 \times 10^{-3} \mathrm{M}$ for A-C) were added to a solution of $\mathbf{1}\left(1.5 \times 10^{-5} \mathrm{M}\right)$ or $2(1.6 \times$ $\left.10^{-5} \mathrm{M}\right)$.

\section{${ }^{1}$ H NMR titrations}

Guests and hosts molecules were dissolved in $\mathrm{CDCl}_{3}$. Titrations were performed at $18{ }^{\circ} \mathrm{C}$ by adding seven aliquots of 
$\mathbf{G}\left(2 \times 10^{-2} \mathrm{M}\right)$ or $\mathbf{A}\left(5 \times 10^{-3} \mathrm{M}\right)$ guest stock solutions to $1 \times$ $10^{-3} \mathrm{M}$ solutions of the hosts.

The experimental data were fitted using non-linear leastsquares regression with Microcal Origin 7 program.

\section{Computational method}

DFT methodologies were chosen to optimize the structure of the bis crown ether receptors, the amine salts and the complexes because they provide a good quality description of the conformational features of this type of systems [28, 35] and a qualitative correct picture of the relative stabilities of hydrogen bonded complexes $[32,33]$. In this case, the B3LYP functional was used with a double- $\zeta$ split valence basis set with one set of polarization functions on all atoms, $6-31 G(p)$. The relative stabilities of the studied complexes at this level of calculation allow for a qualitative picture of the interactions involved in the binding process. The study of some structural modifications of the receptor molecule will help to understand the structural and electronic effects resulting of connecting two crown ether units. All calculations were done using the Gaussian 03 suite of programs [36].

\section{Synthesis of receptors}

The synthetic route [22] for the receptors is shown in Scheme 1. Molecules $\mathbf{1}$ and $\mathbf{2}$ were synthesized by the procedure below described using molecule $\mathbf{1}$ as an example. $0.0392 \mathrm{~g}$ $(0.292 \mathrm{mmol})$ of terephthaldehyde and $0.193 \mathrm{~g}(0.592 \mathrm{mmol})$ of 4-aminobezo-18-crown-6 were dissolved in ethanol (10 $\mathrm{mL}$ ) in a $25 \mathrm{~mL}$ round bottom flask and stirred for 6 hours under reflux. When the reaction was completed a yellowish fine solid was formed. The product was recovered by filtration, washed with acetone $(2 \times 5 \mathrm{~mL})$ and dried under vacuum. Yield $80 \%$. Anal. Calc. for $\mathrm{C}_{40} \mathrm{H}_{52} \mathrm{~N}_{2} \mathrm{O}_{12}$ : C, 63.81; $\mathrm{H}, 6.95 ; \mathrm{N}, 3.72 \%$ found $\mathrm{C}, 63.20 ; \mathrm{H}, 7.01 ; \mathrm{N}, 3.89 \% .{ }^{1} \mathrm{H}$ NMR $\left(\mathrm{CDCl}_{3}, 400 \mathrm{MHz}\right.$, reference TMS, see Scheme 1 for labels): $\delta 3.65$ (m, 2H, H-23), 3.65 (m, 2H, H-22), 3.68 (m, $2 \mathrm{H}, \mathrm{H}-18), 3.68$ (m, 2H, H-21), 3.74 (m, 2H, H-19), 3.74 (m, 2H, H-20), 3.90 (dd, 2H, H-16), 3.90 (dd, 2H, H-17), 4.15 (dd, 2H, H-14), 4.15 (dd, 2H, H-15), 6.80 (d, 1H, H-8), 6.85 (d, 1H, H-10), 6.87 (dd, 1H, H-11), $7.92(\mathrm{~s}, 1 \mathrm{H}, \mathrm{H}-1)$, 8.47 (s, $1 \mathrm{H}, \mathrm{H}-7) \cdot{ }^{13} \mathrm{C}$ NMR $\left(\mathrm{CDCl}_{3}, 100 \mathrm{MHz}\right.$, reference TMS): $\delta$ 69.25(C-15), 69.63(C-14), 69.82(C-16), 69.91(C17), 71.00(C-23), 71.00(C-22), 71.00(C-21), 71.00(C-19), 71.13(C-20), 71.13(C-18), 108.06(C-10), 113.26(C-8), 114.54(C-11), 129.07(C-1), 138.66(C-5, C-6), 145.45(C-9), 148.03(C-12), 149.49(C-13), 157.76(C-7). MS (FAB+) $\mathrm{m} / \mathrm{z}=$ $754[\mathrm{M}+\mathrm{H}]^{+}$. mp $200-203{ }^{\circ} \mathrm{C} . \mathrm{MeOH} / \mathrm{CH}_{2} \mathrm{Cl}_{2}(8: 92) \varepsilon_{387 \mathrm{~nm}}=$ $35073 \pm 472 \mathrm{~cm}^{-1} \mathrm{M}^{-1}$.

2. Yield $60 \%$. Anal. Calc. for $\mathrm{C}_{40} \mathrm{H}_{52} \mathrm{~N}_{2} \mathrm{O}_{12}$ : C, 63.81; H, $6.95 ; \mathrm{N}, 3.72 \%$ found $\mathrm{C}, 62.99 ; \mathrm{H}, 6.91 ; \mathrm{N}, 3.79 \% .{ }^{1} \mathrm{H}$ NMR $\left(\mathrm{CDCl}_{3}, 400 \mathrm{MHz}\right.$, reference TMS $): \delta 3.70(\mathrm{~m}, 2 \mathrm{H}, \mathrm{H}-$
23), $3.70(\mathrm{~m}, 2 \mathrm{H}, \mathrm{H}-22), 3.74(\mathrm{~m}, 2 \mathrm{H}, \mathrm{H}-18), 3.74(\mathrm{~m}$, 2H, H-21), 3.78 (m, 2H, H-19), 3.78 (m, 2H, H-20), 3.95 (dd, 2H, H-16), 3.95 (dd, 2H, H-17), 4.20 (dd, 2H, H-14), $4.20(\mathrm{dd}, 2 \mathrm{H}, \mathrm{H}-15), 6.83(\mathrm{~d}, 1 \mathrm{H}, \mathrm{H}-8), 6.85(\mathrm{~d}, 1 \mathrm{H}, \mathrm{H}-$ 10) $6.90(\mathrm{dd}, 1 \mathrm{H}, \mathrm{H}-11), 7.56(\mathrm{dd}, 1 \mathrm{H}, \mathrm{H}-3), 8.00(\mathrm{~d}, 1 \mathrm{H}$, $\mathrm{H}-2, \mathrm{H}-4), 8.36$ (s, 1H, H-1), 8.55 (s, 1H, H-7). ${ }^{13} \mathrm{C}$ NMR $\left(\mathrm{CDCl}_{3}, 100 \mathrm{MHz}\right.$, reference TMS): $\delta 69.18(\mathrm{C}-15), 69.58(\mathrm{C}-$ 14), 69.80(C-16), 69.89(C-17), 70.97(C-23), 70.97(C22), 70.97(C-21), 70.97(C-18), 71.10(C-20), 71.10(C-19), 107.99(C-10), 113.14(C-8), 114.53(C-11), 129.14(C-1), 129.38(C-3), 130.94(C-2, C-4), 137.01(C-5, C-6), 145.42(C9), 147.90(C-13), 149.46(C-12), 157.93(C-7). MS(FAB $\left.{ }^{+}\right) \mathrm{m} / \mathrm{z}$ $=754[\mathrm{M}+\mathrm{H}]^{+} \cdot \mathrm{mp} 117-119{ }^{\circ} \mathrm{C} \cdot \mathrm{MeOH} / \mathrm{CH}_{2} \mathrm{Cl}_{2}(8: 92) \varepsilon_{352 \mathrm{~nm}}$ $=30847 \pm 529 \mathrm{~cm}^{-1} \mathrm{M}^{-1}$.

Monoimine (NB18C6) was prepared from benzaldehyde according to procedure described to receptors $\mathbf{1}$ and $\mathbf{2}$.

\section{Acknowledgements}

We thank Professor A. K. Yatsimirsky for the advice and fruitful discussion of the results. SRL thanks CONACyT for the $\mathrm{Ph}$. D. Fellowship. This work was supported by CONACyT, projects 39574-Q and 60747.

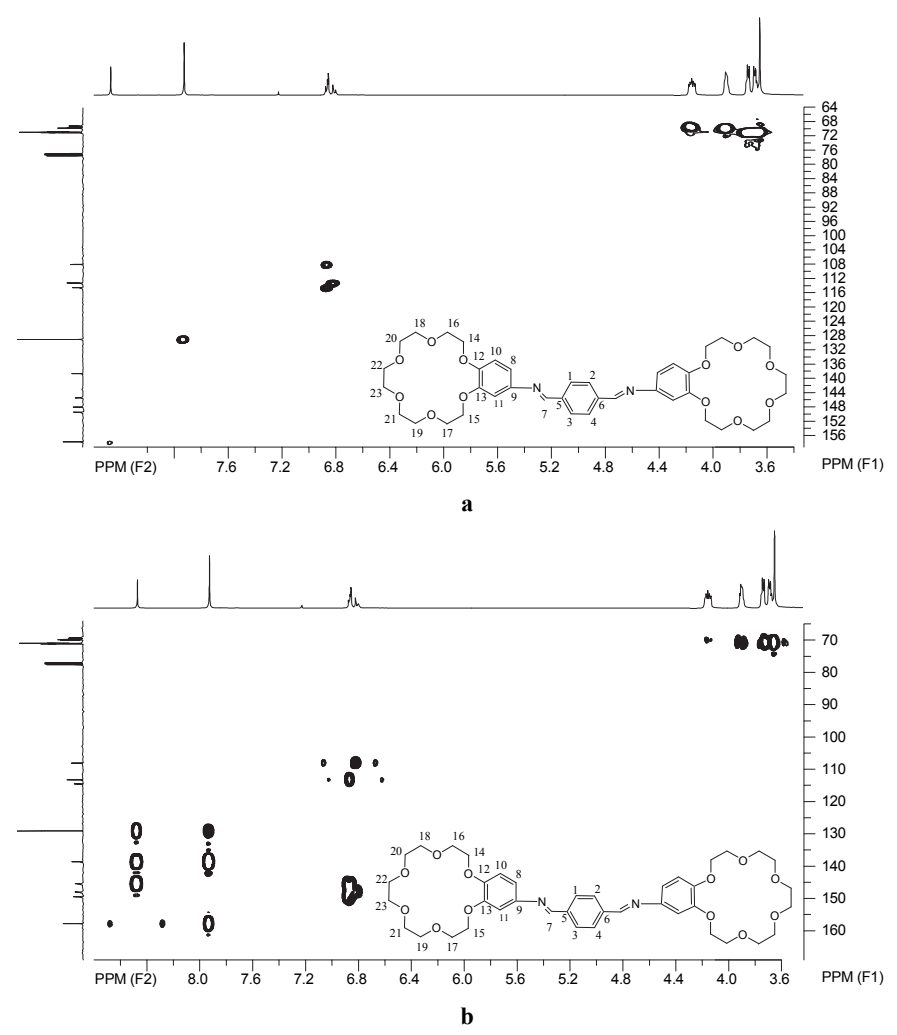

Fig. S1. HSQC and HMBC spectra for $\mathbf{1}$ and 2 in $\mathrm{CDCl}_{3}$. Effect of the methanol concentration over $380 \mathrm{~nm}$ absorbance band of receptor 1 in $\mathrm{CH}_{2} \mathrm{Cl}_{2}$. 

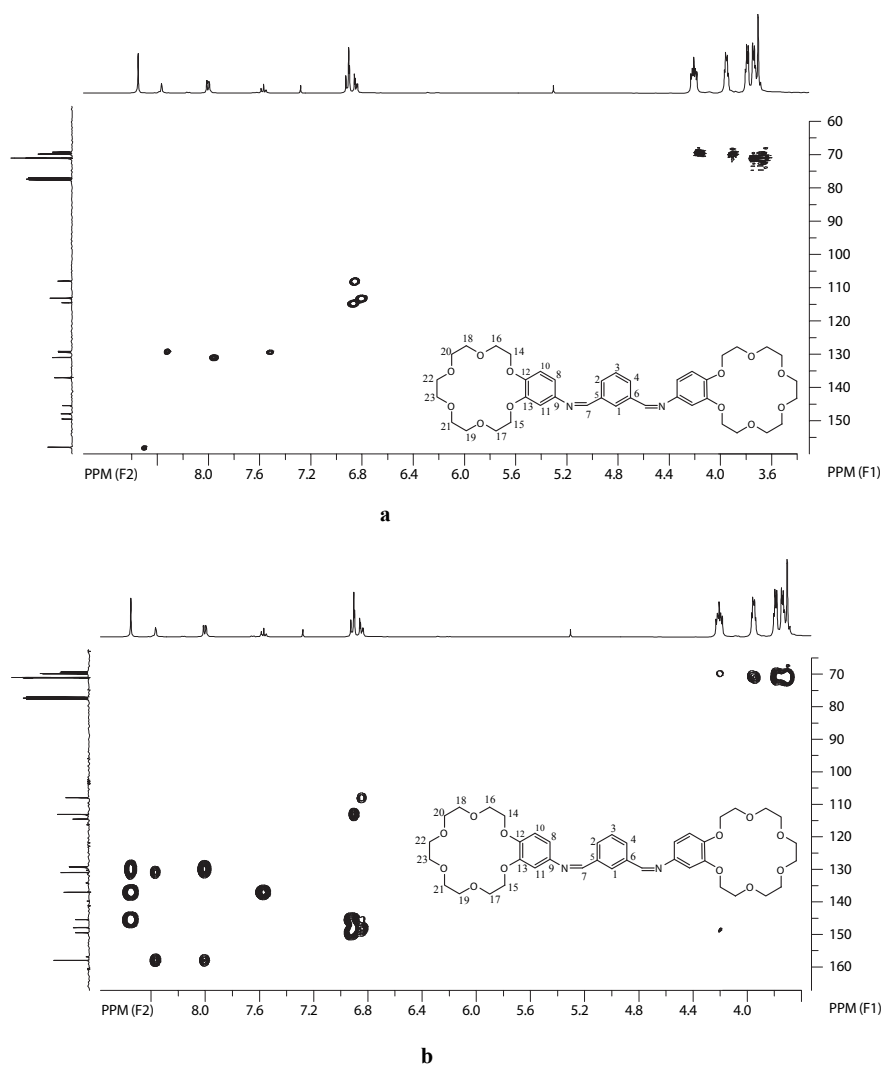

Fig. S2. a) $\mathrm{HSQC}$ and b) $\mathrm{HMBC}$ for $\mathbf{2}$ in $\mathrm{CDCl}_{3}$.

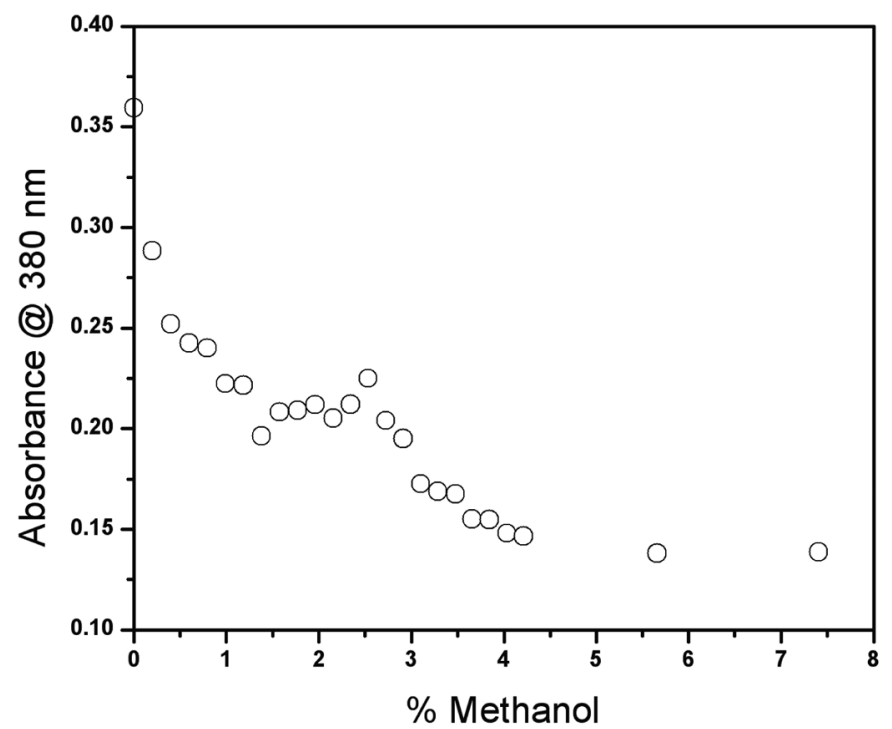

Fig. S3. Effect of the methanol concentration over $380 \mathrm{~nm}$ absorbance band of receptor $1\left(4.3 \times 10^{-6} \mathrm{M}\right)$ in $\mathrm{CH}_{2} \mathrm{Cl}_{2}$.

\section{References}

1. Guy, P. A.; Gremaud, E.; Richoz, J.; Turesky, R. J. J. Chromatogr., A 2000, 883, 89-102.
2. (a) Ohgaki, H.; Takayama, S.; Sugimura, T. Mutat. Res. 1991, 259, 399-410. (b) Wakabayashi, K.; Nagao, M.; Esumi, H.; Sugimura, T. Cancer Res.1992, 52, 2092S-2098S.

3. (a) Sutherland, I. O. Pure Appl. Chem. 1989, 61, 1547-1554. (b) Voyer, N.; Lamothe, J. Tetrahedron 1995, 51, 9241-9284. (c) Gokel, G. W.; Abel, E. Comprehensive Supramolecular Chemistry; Vol. 1, Elsevier: Oxford, England, 1996;.(d) Gokel, G. W.; Leevy, W. M.; Weber, M. E. Chem. Rev. 2004, 104, 27232750 .

4. (a) Hayashi, T.; Nonogushi, M.; Aya, T.; Ogoshi, H. Tetrahedron Lett.1997, 38, 1603. (b) Ema, T.; Misawa, S.; Nemugaki, S.; Sakai, T.; Utaka, M. Chem. Lett. 1997, 487-488.

5. (a)Tsubacki, K.; Kusumoto, T.; Hayashi, N.; Nuruzzaman, M.; Fuji, K. Org. Lett. 2002, 4, 2313-2316. (b) de Silva, A. P.; Sandanayake, K. R. A. S. Angew. Chem. Int. Ed. Engl. 1990, 29, 1173-1175.

6. (a) Feuster, E. K.; Glass, T. E. J. Am. Chem. Soc. 2003, 125, 16174-16175.(b) Mohr, G. J. Chem. Eur. J. 2004, 10, 1082-1090.

7. (a) Zimmerman, S. C.; Wendland, M. S.; Rakow, N. A.; Zharov, I.; Suslick, K. S. Nature 2002, 418, 399-402. (b) Mertz, E.; Zimmerman, S. C. J. Am. Chem. Soc. 2003, 125, 3424-3425.

8. Colera, M.; Costero, A. M.; Gaviña, P.; Gil, S. Tetrahedron: Asymmetry 2005, 16, 2673-2679.

9. Jung, Y. E., Song, B. M., Chang, S.-K. J. Chem. Soc. Perkin Trans. 2 1995, 2031-2034.

10. Voyer, N.; Deschênes, D.; Bernier, J.; Roby, J. J. Chem. Soc., Chem. Commun. 1992, 134-136.

11. Hernández, J. V.; Oliva, A. I.; Simón, L.; Muñiz, F. M.; Grande, M.; Morán, J. R. Tetrahedron Lett. 2004, 45, 4831-4833.

12. Tsubaki, K., Tanaka, H., Furuta, T., Tanaka, K., Kinoshita, T., Fuji, K. Tetrahedron 2002, 58, 5611-5617.

13. Galán, A.; Andreu, D.; Echavarren, A. M.; Prados, P.; De Mendoza, J. J. Am. Chem. Soc. 1992, 114, 1511-1512.

14. Reetz, M. T.; Huff, J.; Rudolph, J.; Töllner, K.; Deege, A.; Goddard, R. J. Am. Chem. Soc. 1994, 116, 11588-11589.

15. Barboiu, M. D.; Hovnanian, N. D.; Luca, C.; Cot, L. Tetrahedron 1999, 55, 9221-9232.

16. Demirel, N.; Bulut, Y.; Hosgören, H. Tetrahedron: Asymmetry 2004, 15, 2045-2049.

17. Breccia, P.; Van Gool, M.; Pérez-Fernández, R.; MartínSantamaría, S.; Gago, F.; Padros, P.; De Mendoza, J. J. Am. Chem. Soc. 2003, 125, 8270-8284.

18. Hansson, A. P.; Norrby, P.-O.; Wärnmark, K. Tetrahedron Lett. 1988, 39, 4565-4568.

19. Kryatova, O. P., Kolchinski, A. G., Rybak-Akimova, E. V. Tetrahedron 2003, 231-239.

20. Izatt, R. M.; Lamb, J. D.; Izatt, N. E.; Rossiter, B. E. Jr., Christensen, J. J., Haymore. B. L. J. Am. Chem. Soc. 1979, 101, 6273-6276.

21. Buschmann, H.-J.; Schollmeyer, E.; Mutihac, L. J. Inclusion Phenom. Macrocyclic Chem. 2001, 40, 199-202.

22. (a) Defen, W.; Xiaoqiang, S.; Dengjin, W.; Hongwen, H. Youji Huaxue 1987, 3, 219-223. (b) Xiaochun, Ch.; Defen, W.; Denjing, W.; Hongwen, H. Chem. Res. Chin. Univ. 1991, 7, 255-260. (c) Dengjin, W.; Defen, W.; Xiaoqiang, S.; Hongwen, H. Gaodeng Xuexiao Huaxue Xuebao 1990, 11(7), 672-675. (d) Defen, W.; Denjing, W.; Hongwen, H. Gaodeng Xuexiao Huaxue Xuebao 1990, 11(3), 276-270.

23. Jaffe, H.H.; Orchin, M. Theory and Applications of Ultraviolet Spectroscopy. John Wiley \& Sons, USA, 1962, p. 186.

24. Connors, K. A. Binding Constants. The Measurement of Molecular Complex Stability. John Wiley \& Sons, USA, 1987, p. 24.

25. Schneider, H.-J.; Yatsimirsky, A. K.: Principles and Methods in Supramolecular Chemistry. John Wiley \& Sons, England, 2000, p.142.

26. Marquis, D.; Desvergne, J.-P.; Bouas-Laurent, H. J. Org. Chem. 1995, 60, 7984-7996. 
27. Gaviña, F.; Luis, S.V.; Costero, A.M.; Burgete, M.I.; Rebek, J. J. Am. Chem. Soc. 1988, 110, 7140-7143.

28. Al-Jallal, N. A.; Al-Kahtani, A. A.; El-Azhary, A. A. J. Phys. Chem. A, 2005, 109(16), 3694-3703.

29. Buschmann, H. -J.; Mutihac, L.; Jansen, K. J. Inclusion Phenom. Macrocyclic Chem. 2001, 39, 1-11.

30. Zhu, L.-N.; Gao, S.; Huo, L.-H. Acta Cryst. E63 2007, 04924.

31. Lehn, J. M., Supramolecular Chemistry VCH, Germany, 1995, p. 26-28.

32. Ramírez, J. Z.; Vargas, R.; Garza, J. J. Mex. Chem. Soc. 2008, 52, 31-35.

33. Guo, H.; Sirois, S.; Proynov, E. I.; Salahub, D. R. Density Functional Theory and its Applications to Hydrogen-bonded Systems. Theoretical Treatments of Hydrogen bonding; Hadži, D., Ed.; John Wiley \& Sons Ltd: Chichister, UK, 1997.

34. Vogel, A. I.; Tatchell, A. R.; Furnis, B. S.; Hannaford, A. J.; Smith, P.W.G. Vogel's Textbook of Practical Organic Chemistry.5th Edition. Prentice Hall, 1989.

35. Shishkina, S. V.; Shishkin, O. V.; Grygorash R. Y.; Mazepa, A. V.; Rakipov, I. M.; Yakshin, V. V.; Kotlyar, S. A.; Kamalov, G. L. J. Molecular Struct. 2007, 832 199-208
36. Gaussian 03, Revision D.01, M. J. Frisch, G. W. Trucks, H. B. Schlegel, G. E. Scuseria, M. A. Robb, J. R. Cheeseman, J. A. Montgomery, Jr., T. Vreven, K. N. Kudin, J. C. Burant, J. M. Millam, S. S. Iyengar, J. Tomasi, V. Barone, B. Mennucci, M. Cossi, G. Scalmani, N. Rega, G. A. Petersson, H. Nakatsuji, M. Hada, M. Ehara, K. Toyota, R. Fukuda, J. Hasegawa, M. Ishida, T. Nakajima, Y. Honda, O. Kitao, H. Nakai, M. Klene, X. Li, J. E. Knox, H. P. Hratchian, J. B. Cross, V. Bakken, C. Adamo, J. Jaramillo, R. Gomperts, R. E. Stratmann, O. Yazyev, A. J. Austin, R. Cammi, C. Pomelli, J. W. Ochterski, P. Y. Ayala, K. Morokuma, G. A. Voth, P. Salvador, J. J. Dannenberg, V. G. Zakrzewski, S. Dapprich, A. D. Daniels, M. C. Strain, O. Farkas, D. K. Malick, A. D. Rabuck, K. Raghavachari, J. B. Foresman, J. V. Ortiz, Q. Cui, A. G. Baboul, S. Clifford, J. Cioslowski, B. B. Stefanov, G. Liu, A. Liashenko, P. Piskorz, I. Komaromi, R. L. Martin, D. J. Fox, T. Keith, M. A. Al-Laham, C. Y. Peng, A. Nanayakkara, M. Challacombe, P. M. W. Gill, B. Johnson, W. Chen, M. W. Wong, C. Gonzalez, and J. A. Pople, Gaussian, Inc., Wallingford CT, 2004. 